\title{
La passation de savoir : stratigraphie d'une enquête sur le tissage au Mexique
}

\section{Marie-Noëlle Chamoux}

\section{(2) OpenEdition}

1 Journals

Édition électronique

URL : https://journals.openedition.org/tc/463

DOI : $10.4000 /$ tc.463

ISSN : 1952-420X

Éditeur

Éditions de l'EHESS

\section{Édition imprimée}

Date de publication : 1 novembre 1997

ISSN : 0248-6016

\section{Référence électronique}

Marie-Noëlle Chamoux, "La passation de savoir : stratigraphie d'une enquête sur le tissage au Mexique », Techniques \& Culture [En ligne], 28 | 1997, mis en ligne le 28 octobre 2005, consulté le 29 septembre 2022. URL : http://journals.openedition.org/tc/463 ; DOI : https://doi.org/10.4000/tc.463

Ce document a été généré automatiquement le 29 septembre 2022.

Tous droits réservés 
La passation de savoir : stratigraphie d'une enquête sur le tissage au Mexique

Marie-Noëlle Chamoux 